\title{
MORINGA OLEIFERA PLANT "VALUE AND UTILIZATION IN FOOD PROCESSING "
}

\author{
EL - MASSRY, FATMA H. M., M. E. M. MOSSA and \\ S. M. YOUSSEF
}

Horticultural Crops Res. Dept., Food Tech. Res. Inst., ARC, Giza.

(Manuscript received 31 July 2013)

\begin{abstract}
Some physical properties and chemical composition of Moringa different parts such as (seedless pods, seeds, fresh and dried leaves ) were investigated. The obtained data reveal that the seeds and dried leaves of Moringa oleifera are good sources for ether extract, crude protein, ash and also crude fibers. Minerals contents of Moringa different parts were studied and the obtained results indicate that the Moringa oleifera crop is also rich in many important minerals especially ( $\mathrm{Ca}, \mathrm{K}, \mathrm{Mg}, \mathrm{P}, \mathrm{Cu}, \mathrm{Fe}$ and $\mathrm{Zn})$. The amino acids were determined in Moringa different parts where eighteen amino acids were identified. It contains the major essential amino acids, as well as argenine and glutamic acids in high percentages in Moringa different parts if compared to other amino acids. The results also reveal that the different parts of Moringa are rich sources for natural antioxidants and total antioxidant activity. Also, phenolic compounds of Moringa different parts were analyzed and the results indicate that the quercetin ,caffeic acid and kaempferol are predominant phenolic compounds in Moringa pods and seeds. Whereas, the rutin , caffeic and ferulic acid are the dominant phenolic constituents of Moringa leaves extracts. Sensory evaluation characteristics of Moringa products show greater preference especially tea with $25 \%$ for both dried peppermint and dried cloves, cooked Moringa seeds and Moringa juice + pineapple juice $(1: 1, \mathrm{~V} / \mathrm{V})$, had the highest scores for color, taste ,odor, texture, and overall palatability. Finally, it is recommended through this investigation that the Moringa crop is suitable for both cultivation and food processing in Egypt.

Key words : Moringa oleifera, physical properties, chemical composition, amino acids, antioxidant activity, phenolic compounds and products.
\end{abstract}

\section{INTRODUCTION}

Edible wild indigenous plants become an alternative source for food possessing high potential of vitamins, minerals and other interesting elements particularly during seasonal food storage. Wild fruits are also known to have nutritional and medicinal properties that could be attributed to their antioxidant effects as well as being used to fortify stable foods particularly for malnourished children (Compaore et al., 2011). Moringa oleifera Lam (Moringa ceae) is one of those aforementioned fruits. Its origin referred to western and sub - Himalayan region, India, Pakistan, Asia minor, Africa 
and Arabia. Now it is distributed in the Philippines, Cambodia, Central, North and South American and the Caribbean Islands.

Moringa oleifera is a tropical tree possessing numerous economic applications. Plus growing international interest., moringa tree is cultivated and used as a vegetable (leaves, green pods, flowers, roasted seeds ), for spice (mainly roots ), for cooking and cosmetic oil ( seeds ) and as a medicinal plant ( all plant organs ), ( Rebecca et al., 2006 ).

Moringa oleifera is a highly valuable plant, distributed in many tropical and subtropical countries. It has an impressive range of medicinal uses with high nutritional value. Different parts of this plant contain a profile of important minerals, and are a good source for protein, vitamins, B - carotene, amino acids and various phenolics. Moringa plant provides a rich and rare combination of zeatin, qurcetin, kaempferol and many other phytochemicals. It is also very important plant for it,s medicinal value. Various parts of the plant such as leaves, roots, seeds, bark, fruit, flowers and immature pods etc as cardiac and circulatory stimulants, posses antitumour, antipyretic, antitiepileptic, anti-inflammatory, antiulcer, antispasmodic, antihypertensive, cholesterol lowering, antioxidant, antidiabetic, antibacterial and antifungal ( Bukar et al., 2010 ).

In the west, one of the best known use for Moringa is utilization of powdered seeds to flocculate contaminates to purify drinking water. The seeds are also eaten green, roasted, powdered and steeped for tea or used in curries.

Recently, this tree has been advocated as an outstanding indigenous source of highly digestible protein, $\mathrm{Ca}$, $\mathrm{Fe}$, vitamin $\mathrm{C}$, and carotenoids suitable for utilization in many of the so - called "developing" regions of the world where under nourishment is a major concern ( Jed, 2005 ).

The seeds of Moringa oleifera are particularly rich in proteins $(35.37 \pm 0.07 \mathrm{~g} /$ $100 \mathrm{~g}$ ), lipids ( $43.56 \pm 0.03 \mathrm{~g} / 100 \mathrm{~g}$ ) and minerals ( $\mathrm{Mg}$ and $\mathrm{Zn}$ ). Seeds of Moringa oleifera had also the strongest radicals scavenging activity ( $99.74 \%$ ) and flavonoids content ( Compaore et al., 2011 ).

Busani et al., ( 2011 ) found that the dried leaves had crude protein levels of $30.0 \%$ and 19 amino acids. The dried leaves had the following mineral contents: calcium(3.65 \%), phosphorus( $0.3 \%$ ), magnesium ( $0.5 \%$ ), potassium ( $1.5 \%$ ), sodium ( $0.164 \%$ ), sulphur ( $0.63 \%)$, zinc ( $13.03 \mathrm{mg} / \mathrm{kg})$, copper ( $8.25 \%)$, manganese ( $86.8 \mathrm{mg} / \mathrm{kg}$ ), iron ( $490 \mathrm{mg} / \mathrm{kg}$ ) and selenium ( $363 \mathrm{mg} / \mathrm{kg}$ ). The values of amino acids, minerals and vitamins profiles reflect desirable nutritional balance.

Thus, this study is an attempt to evaluate accurately the chemical composition of Moringa plant, besides fixing the most significant nutritional components in that aforementioned plant. 
The aim is also extended to investigate the possibility of utilization of some Moringa by-product parts such as leaves and hulls for sanitary food and or / food processing.

\section{MATERIALS AND METHODS}

\section{Materials:}

The fresh seedless pods, seeds and leaves of Moringa plants (Moringa oleifera ) were obtained from Horticultural Research Institute, Agric. Res. Center, Giza, and transferred then frozen and stored at $-18^{\circ} \mathrm{C}$ until analysis and processing.

A part of the fresh leaves appropriated has been dried at $45^{\circ} \mathrm{C}$ for approximately 6 hours in an oven, then minced to powder by milling using a locally Milling machine and then kept in plastic sachets at room temperature $\left(25^{\circ} \mathrm{C}\right)$.

The chemical composition analyses has been performed in triplicate for all investigated samples.

\section{Preparation of Moringa oleifera products:}

The leaves were harvested in the green form, dried in an oven and milled into powder, then processed to Moringa tea. Also, Moringa leaves powder was mixed with $25 \%$ (W/W) peppermints and $25 \%$ ( W/W ) cloves powders, respectively, to make tea drinks. Whereas, seeds of Moringa were cooked by conventionally method in houses such as green peas.

All Moringa oleifera products and juices were prepared according to the methods of ( Cruess, 2000 ).

\section{Methods:}

Moisture, crude protein, ether extract, ash, crude fiber and carbohydrates were determined by using the methods of the AOAC (2000).

Minerals content ( $\mathrm{Na}, \mathrm{Ca}$ and $\mathrm{K}$ ) were determined in the diluted solution of ash samples by using emission flam photometer ( Model Corning 410 ).

The other minerals $(\mathrm{Cu}, \mathrm{Zn}, \mathrm{Mn}, \mathrm{Fe}, \mathrm{P}$ and $\mathrm{Mg}$ ) were determined by Atomic absorption spectrophotometer ( PerKin - Elmer Instrument Model 2380 ).

Amino acids were determined using Amino Acid Analyzer (LC 3000), according to the methods of (Bassler and Buchholz, 1993).

\section{Determination of total antioxidant activity of samples:}

Antioxidant activity was determined according to the method described by Zhang and Hamauzu (2004) as follows: Five grams of Moringa different parts were extracted by $100 \mathrm{ml} .80 \%$ methanol. Different concentrations (10 to $50 \mu \mathrm{ml}$ ) were used to determine the antioxidant activity using 2,2 - diphenyl - 1 - picryl hydroxyl (DPPH). Total phenolics were estimated according to AOAC (1990), by using photometric method with Folin reagent. Flavonoids were extracted and determined according to Zhuang et al., ( 1992 ). Carotenoids including B - carotene plus ascorbic acid were determined according to AOAC ( 1990 ). 
Determination of phenolic compounds: Extraction, separation and quantification of phenolic compounds were determined according to the method described by Goupy et al., (1999).

\section{Sensory evaluation and statistical analysis:}

Sensory evaluation of Moringa products different properties were carried out by ten panelists on the sensory parameters. Data were recorded as means and analyzed by ( SPSS ) Windows ( Ver.10.1 ). One - way analysis of variance (ANOVA) and Duncan comparisons were tested to signify differences between different treatments of seeds and leaves Moringa oleifera.

\section{RESULTS AND DISCUSSION}

\section{Some physical properties of Moringa oleifera pods and seeds:}

Data concerning that point are shown in Table (1). From that aforementioned table, it could be clearly observed that Moringa oleifera has very characteristic physical properties such as weight of every pod, every 100 pod, every seed, every 100 seeds. It is also noticed through that table that the number of seeds in every pod of Moringa oleifera is perhaps higher than that any other famous vegetable such as peas or green bean indicating that Moringa oleifera pods are full seeds and not empty such as hraty bean (sometimes).

Table 1. Some physical properties of pods and seeds of Moringa oleifera

\begin{tabular}{|l|c|}
\hline Characteristics & Values \\
\hline Average weight of pod $(\mathrm{g})$ & 7.68 \\
Average weight of 100 pod $(\mathrm{g})$ & 768 \\
Average weight of seeds ( g ) / pod & 4.73 \\
Average weight ( g ) / 100 seeds & 31.24 \\
Average number of seeds / pod & 16 \\
Average weight of kernel ( g ) / 100 seeds & 21.69 \\
Percent weight of kernel in relation to entire seed & 73.67 \\
Percent weight of hull in relation to entire seed & 26.33 \\
Moisture in kernel ( \% ) & 5.78 \\
Moisture in hull ( \% ) & 11.32 \\
Moisture in whole seed $(\%)$ & 6.89 \\
\hline
\end{tabular}

From the same Table ( 1 ), it could be also obviously concluded that Moringa oleifera ( kernel, hull and seed ) has very optimum moisture content, which means that this crop is naturally protected against both spoilage and deterioration.

On the other hand, Hamed ( 1980 ), reported that the moisture contents of green peas pods and seeds were 25.82 and $23.75 \%$, respectively. These values of moisture contents in green peas crop were very high if compared to those of our investigated moringa. 


\section{Chemical composition of different parts of Moringa (Moringa oleifera):}

The chemical composition of different parts of Moringa such as pods (seedless), seeds, fresh and dried leaves for their moisture content, crude protein, ether extract, ash, crude fiber and total carbohydrates are shown in Table ( 2 ).

The results of the proximate composition (Table 2 ) revealed that seeds of Moringa oleifera, as other legumes, are good sources for ether extract, proteins and crude fibers. It contained 44.78, 25.97 and $4.87 \%$ (on dry weight basis), respectively.Also,dried leaves contained high amounts of protein and crude fibers which were 26.79 and $18.67 \%$, respectively. On the other hand, other parts of Moringa oleifera contained, lower contents than those reported for seeds and dried leaves recorded in the same aforementioned Table ( 2 ).

Table 2. Chemical composition of Moringa oleifera different parts*

\begin{tabular}{|l|c|c|c|c|}
\hline \multirow{2}{*}{ Components *** } & \multicolumn{4}{|c|}{ Moringa parts } \\
\cline { 2 - 5 } & Pods** & Seeds & Fresh leaves & Dried leaves \\
\hline Moisture (\% ) & $85.65 \pm 0.3$ & $4.67 \pm 1.8$ & $74.32 \pm 2.1$ & $5.48 \pm 2.3$ \\
Crude protein ( \% ) & $17.20 \pm 0.7$ & $25.97 \pm 2.1$ & $20.94 \pm 2.4$ & $26.79 \pm 1.8$ \\
Ether extract (\% ) & $0.44 \pm 0.2$ & $44.78 \pm 0.5$ & $5.75 \pm 0.8$ & $4.98 \pm 1.5$ \\
Ash (\%) & $12.33 \pm 0.2$ & $5.22 \pm 0.6$ & $3.64 \pm 0.7$ & $7.92 \pm 0.9$ \\
Crude fibers (\% ) & $34.96 \pm 0.3$ & $4.87 \pm 0.5$ & $7.68 \pm 1.1$ & $18.67 \pm 0.8$ \\
Total carbohydrates (\% ) & $26.37 \pm 2.1$ & $14.41 \pm 2.3$ & $37.85 \pm 1.2$ & $35.90 \pm 1.2$ \\
\hline Energy (Kcal / 100 g ) & 178.24 & 564.54 & 286.91 & 295.58 \\
\hline
\end{tabular}

* Data are means values \pm standard deviation (SD) of duplicate results.

** Seedless pods.

***Components calculated on dry weight basis.

Also, results in the same pervious Table ( 2 ) show that the total carbohydrates contents were higher in fresh and dried leaves of Moringa oleifera, which were 37.85 and $35.90 \%$, respectively. In addition the ash content was 3.64 and $7.92 \%$, respectively ( Table, 2 ).

Conclusively, it could be observed that the seeds and leaves of Moringa oleifera are good sources for ether extract, crude protein, ash and crude fiber as other legumes.

Those results are in agreement with these reported by Compaore et al., (2011), who found that the seeds of Moringa are particularly rich in protein( $35.37 \%$ ) and lipids ( $43.56 \%$ ). Also, Charles et al., ( 2011 ), stated that the percentages ( \% ) of proteins, moisture, fat, carbohydrates of fresh and dried leaves were 11.9, 73.9, 1.1 and 10.6 and $27.2,5.9,17.1$ and $38.6 \%$, respectively. 
Finally, through data tabulated in Table ( 2 ), it could be clearly concluded that different Moringa parts are rich to great extent in many significant components such as protein and carbohydrates.

\section{Mineral contents of different parts of Moringa ( Moringa oleifera):}

Data concerning minerals content are shown in Table ( 3 ), data revealed to great extent the presence of nearly most of different minerals. The results singed to high concentrations calcium ( $\mathrm{Ca}$ ), phosphorus ( $\mathrm{P}$ ), magnesium ( $\mathrm{Mg}$ ), potassium $(\mathrm{K}$ ) and sodium ( $\mathrm{Na}$ ) in dried leaves than those of Moringa other parts. Where concentrations of the aforementioned minerals were 2078.98, 346.87, 403.56, 1498.75 and $72.50 \mathrm{mg} / 100 \mathrm{~g}$ (DWB), respectively.

The seeds contain also the same minerals contents, which were nearly similar to those in Moringa oleifera leaves, which were, 76.85, 524.30, 259.78, 64.24 and 24.92 mg / 100 g (DWB), respectively (Table 3).

On the other hand, Moringa seeds contained appreciable amounts of minerals especially micro - elements such as, zinc $(\mathrm{Z})$, copper $(\mathrm{Cu})$ and manganese $(\mathrm{Mn})$. The values obtained for the micro - elements, $\mathrm{Zn}$ (27.47), $\mathrm{Cu}$ (48.13) and Mn (87.75) mg / $100 \mathrm{~g}$ ( DWB ), respectively (Table, 3).

On contrary, the analysis of minerals showed that the Moringa leaves were good sources for iron ( Fe ) than that found in other parts of Moringa oleifera, which values were, 15.98 and $27.76 \mathrm{mg} / 100 \mathrm{~g}$ ( DWB ) for fresh and dried leaves, respectively.

Table 3. Minerals content in Moringa oleifera different parts*

(mg / $100 \mathrm{~g}$ DWB ).

\begin{tabular}{|l|c|c|c|c|}
\hline \multirow{2}{*}{ Minerals } & \multicolumn{3}{|c|}{ Moringa parts } \\
\cline { 2 - 5 } & Pods** & Seeds & Fresh leaves & Dried leaves \\
\hline Macro - elements & & & & \\
Calcium ( Ca ) & $28.97 \pm 0.4$ & $76.85 \pm 2.1$ & $738.94 \pm 1.1$ & $2078.98 \pm 0.1$ \\
Phosphorus ( P ) & $112.32 \pm 0.3$ & $524.30 \pm 2.3$ & $89.77 \pm 1.3$ & $346.87 \pm 0.3$ \\
Magnesium ( Mg ) & $25.20 \pm 0.1$ & $259.78 \pm 0.9$ & $147.58 \pm 0.9$ & $403.56 \pm 0.8$ \\
Potassium ( K ) & $263.45 \pm 0.17$ & $64.24 \pm 1.8$ & $494.12 \pm 0.8$ & $1498.75 \pm 0.9$ \\
Sodium ( Na ) & $15.34 \pm 0.14$ & $24.92 \pm 1.7$ & $21.95 \pm 1.1$ & $72.50 \pm 0.2$ \\
Micro - elements & & & & \\
Zinc ( Zn ) & $0.34 \pm 3.4$ & $27.47 \pm 1.1$ & $1.18 \pm 2.4$ & $5.43 \pm 1.1$ \\
Copper ( Cu ) & $3.24 \pm 0.19$ & $48.13 \pm 1.3$ & $1.25 \pm 2.1$ & $0.76 \pm 1.2$ \\
Manganese ( Mn ) & $8.38 \pm 2.7$ & $87.75 \pm 0.9$ & $13.49 \pm 0.9$ & $32.45 \pm 0.9$ \\
Iron ( Fe ) & $5.25 \pm 2.3$ & $13.67 \pm 0.8$ & $15.98 \pm 1.1$ & $27.76 \pm 0.8$ \\
& & & & \\
\hline
\end{tabular}

*Data are means values \pm standard deviation ( SD ) of duplicate results.

** Seedless pods.

These results are nearly in agreement with Nzikou et al., ( 2009 ), who have found calcium, magnesium, potassium and sodium values in Moringa oleifera seeds as follows: $83.75,251,36.53$ and $22.5 \mathrm{mg} / 100 \mathrm{~g}$ ( DWB ), respectively. 
Also, Charles et al., ( 2011 ) noticed that the minerals contents for the ( Ca, $\mathrm{Mg}, \mathrm{K}, \mathrm{Fe}, \mathrm{Zn}$ and $\mathrm{P}$ ) were 847.1, 151.3, 549.6, 17.5, 1.3 and 111.5 and 2098.1, 406.0, 1922.0, 28.3, 5.4 and $351.1 \mathrm{mg} / 100 \mathrm{~g}$ ( DWB ) in the fresh and dried Moringa oleifera leaves, respectively.

The results indicated that the Moringa oleifera is an important crop, which has high concentrations in energy releasing nutrients such as lipids and proteins, besides important minerals ( $\mathrm{Ca}, \mathrm{K}, \mathrm{Mg}, \mathrm{P}, \mathrm{Fe}$ and $\mathrm{Zn}$ ).

As it was mentioned for other aforementioned components in seeds, leaves and pods in Moringa oleifera, it has been also proved through chemical analysis that crop (Moringa oleifera) is also rich in many important minerals.

\section{Amino acids of different parts of Moringa (Moringa oleifera):}

Amino acids contents and types are very important parameters for evaluating the protein.

Results of the amino acids composition of Moringa different parts are recorded in Table ( 4 ).

The results indicated that the different parts of Moringa oleifera contained 18 (eighteen) amino acids.

Results in Table ( 4 ), indicated that argenine, glutamic acid and cystine in Moringa oleifera seeds protein were the most predominant amino acids which contents are 12.68, 18.76 and $4.59 \mathrm{~g} \mathrm{/} 16 \mathrm{~g} \mathrm{~N}$, respectively. On the other hand, Moringa oleifera leaves contained high amount of other amino acids, especially essential amino acids such as, methionine, valine, phenylalanine, leucine, lysine and tryptophan, which were 2.12, 6.47, 6.38, 10.12, 6.73 and $2.17 \mathrm{~g} / 16 \mathrm{~g} \mathrm{~N}$, respectively, ( Table 4 ). It could be also observed that the Moringa oleifera is reported to have high quality protein which could be easily digested and that is influenced by the quality of its amino acids ( Foidl et al., 2001 ). 
Table 4. Amino acids composition $(\mathrm{g} / 16 \mathrm{~g} \mathrm{~N})$ in different parts of Moringa (Moringa oleifera ).

\begin{tabular}{|l|c|c|c|c|}
\hline \multirow{2}{*}{ Amino acids } & \multicolumn{4}{|c|}{ Moringa parts } \\
\cline { 2 - 5 } & Pods** & Seeds & Fresh leaves & Dried leaves \\
\hline Arginine & 8.84 & 12.68 & 7.12 & 6.34 \\
Serine & 2.09 & 2.59 & 4.87 & 4.22 \\
Aspartic acid & 3.13 & 4.34 & 10.79 & 8.98 \\
Glutamic acid & 14.71 & 18.76 & 11.93 & 10.64 \\
Glycine & 3.72 & 5.34 & 6.23 & 5.58 \\
Threonine* & 1.70 & 2.45 & 5.15 & 4.85 \\
Alanine & 2.87 & 4.13 & 6.72 & 7.47 \\
Tyrosine* & 1.14 & 1.75 & 4.43 & 3.96 \\
Proline & 4.21 & 5.93 & 6.12 & 5.56 \\
Methionine* & 1.44 & 2.08 & 2.12 & 2.03 \\
Valine* & 2.64 & 3.78 & 6.47 & 5.79 \\
Phenylalanine* & 3.05 & 3.36 & 6.38 & 6.29 \\
Isolucine* & 2.32 & 3.34 & 5.29 & 4.59 \\
Leucine* & 4.13 & 5.73 & 10.12 & 8.89 \\
Histidine* & 1.72 & 2.47 & 3.18 & 3.04 \\
Lysine* & 1.14 & 2.65 & 6.73 & 5.78 \\
Cystine & 3.22 & 4.59 & 1.38 & 1.23 \\
Tryptophan* & 0.56 & 0.69 & 2.17 & 2.12 \\
\hline
\end{tabular}

*General essential amino acids.

** Seedless pods.

These results are in agreement with those reported by Busani et al., ( 2011 ).

\section{Natural antioxidants and antioxidant activities of Moringa different parts:}

Total polyphenols, total flavonoids, ascorbic acid, B-carotene, carotenoids and total antioxidant activity in different parts of Moringa oleifera are shown in Table ( 5 ).

The results shown in Table ( 5 ) revealed that the total polyphonols, total flavonoids and ascorbic acid of different Moringa plant parts ranged from ( 9.57 to 22.38 ), ( 68.97 to 142.20 ) and ( 67.84 to 871.28 ) $\mathrm{mg} / 100 \mathrm{~g}$ ( DWB ), respectively.

On the other hand, B - carotene and carotenoids ranged from ( 0.65 to 28.36 ) and ( 28.94 to 149.95 ) $\mathrm{mg} / 100 \mathrm{~g}$ ( DWB ), respectively in different Moringa plant parts (Table, 5$)$. 
Table 5. Natural antioxidants and total antioxidant activities of different parts* of Moringa oleifera.

\begin{tabular}{|l|c|c|c|c|}
\hline \multirow{2}{*}{ Natural antioxidants } & \multicolumn{4}{|c|}{ Moringa parts } \\
\cline { 2 - 5 } & Pods** & Seeds & Fresh leaves & Dried leaves \\
\hline Total polyphenols $(\mathrm{mg} / 100 \mathrm{~g})$ & $13.71 \pm 0.52$ & $9.57 \pm 0.28$ & $22.38 \pm 1.12$ & $21.56 \pm 0.87$ \\
Total flavonoids $(\mathrm{mg} / 100 \mathrm{~g})$ & $68.97 \pm 0.49$ & $142.20 \pm 0.72$ & $77.95 \pm 1.20$ & $75.98 \pm 0.79$ \\
Ascorbic acid $(\mathrm{mg} / 100 \mathrm{~g})$ & $871.28 \pm 0.32$ & $84.48 \pm 0.71$ & $825.13 \pm 1.17$ & $67.84 \pm 0.72$ \\
B - carotene $(\mathrm{mg} / 100 \mathrm{~g})$ & $0.97 \pm 0.43$ & $0.65 \pm 0.80$ & $28.36 \pm 1.16$ & $17.59 \pm 0.70$ \\
Carotenoids $(\mathrm{mg} / 100 \mathrm{~g})$ & $140.95 \pm 0.64$ & $28.94 \pm 0.79$ & $149.75 \pm 1.10$ & $147.42 \pm 0.67$ \\
Total antioxidant activity (\%) & $133.78 \pm 0.96$ & $166.76 \pm 0.82$ & $168.34 \pm 0.71$ & $167.63 \pm 0.97$ \\
\hline
\end{tabular}

*Data are means values \pm standard deviation ( SD ) of duplicate results.

** Seedless pods.

Total antioxidant activity also ranged from (133.78 to 168.34 ) \%, for pods and leaves of Moringa oleifera, respectively ( Table 5 ).

It could be observed that the different parts of Moringa plants are rich sources for natural antioxidants and total antioxidant activity ( Table 5 ). These results are in agreement with these stated by Compaore et al., 2011 ).

However, from the aforementioned obtained data, it could be clearly concluded that nearly all Moringa oleifera parts ( leaves, pods and seeds ) contained considerable contents of components possessing the property of antioxidant activity. That means that, Moringa worth to be as we mentioned before promising crop which could play an important role as one of the most significant defiance lines of human body against different diseases.

\section{Identification of phenolic compounds of different parts of Moringa oleifera by HPLC analysis:}

Ten phenolic compounds were identified from Moringa different parts by High Performance Liquid Chromatography (HPLC) analysis.The detected phenolic compounds were gallic acid ,chlorogenic acid, ellagic acid ,ferulic acid ,kaempferol ,quercetin ,rutin ,syringic acid ,caffeic acid and catechin are shown in Table (6). 
Table 6. Phenolic compounds of different parts of Moringa oleifera fractionation by HPLC analysis ( $\mathrm{mg} / 100 \mathrm{~g}$ on dry weight basis).

\begin{tabular}{|l|c|c|c|c|}
\hline \multirow{2}{*}{ Phenolic compounds } & \multicolumn{4}{|c|}{ Moringa parts } \\
\cline { 2 - 5 } & Pods* & Seeds & Fresh leaves & Dried leaves \\
\hline Gallic acid & 9.14 & 6.37 & 14.22 & 13.72 \\
Chlorogenic acid & 7.44 & 3.54 & 8.62 & 6.97 \\
Ellagic acid & 1.53 & 0.97 & 4.78 & 2.34 \\
Ferulic acid & 0.75 & 0.52 & 36.79 & 33.80 \\
Kaempferol & 22.23 & 74.13 & 1.80 & 0.74 \\
Quercetin & 42.36 & 16.48 & 28.56 & 27.14 \\
Rutin & 18.54 & 14.25 & 97.68 & 89.69 \\
Syringic acid & 0.53 & 0.44 & 2.66 & 1.27 \\
Caffeic acid & 32.14 & 28.14 & 68.25 & 65.74 \\
Catechin* & 3.25 & 2.96 & 18.16 & 17.29 \\
\hline
\end{tabular}

* Seedless pods.

The highst contents of phenolic compounds were quercetin, kaempferol and rutin for pods, seeds and fresh and dried leaves, respectively. The abovementioned values were $42.36,74.13$ and $97.68 \mathrm{mg} / 100 \mathrm{~g}$ (DWB) , respectively (Table ,6).

Conclusively, results indicate that the quercetin ,caffeic acid and kaempferol were predominant phenolic compounds in Moringa pods and seeds extracts. Whereas, the rutin , caffeic acid and ferulic acid are the dominant phenolic constituents of Moringa leaves extracts (Table ,6)

These results are in agreement with observed by Atawodi et al., (2010), who showed the antioxidant activity of Moringa oleifera extracts is due to the presence of various bioactive compounds such as chlorogenic acid, rutin, quercetin and kaempferol.

\section{Sensory evaluation of Moringa products:}

Data concerning sensory evaluation of some Moringa products are shown in Table (7). From that Table (7), it could be clearly observed that nearly all manufactured Moringa products were almost palatable among different panelists. On the other hand, high scores of different sensory attributes plus overall palatability were given to Moringa tea with $25 \%$ dried peppermint, Moringa tea $+25 \%$ dried cloves, Moringa juice + pineapple juice (1: $1, \mathrm{~V} / \mathrm{V})$ and cooked Moringa seeds, respectively ( Table, 7 ).

It could be indicated through the aforementioned obtained results that it was applicable, successful and available to utilize Moringa crop in producing many palatable and preferable manufactured products.

That proved that Moringa crop has an important technological value as an untraditional new cultivated crop or by other meaning worth to be investigated. 
Table 7. Sensory evaluation of Moringa products.

\begin{tabular}{|c|c|c|c|c|c|}
\hline $\begin{array}{c}\text { Moringa } \\
\text { products }\end{array}$ & Color & Taste & Odor & Texture & $\begin{array}{c}\text { Overall } \\
\text { acceptability }\end{array}$ \\
\hline$(1)$ & $8.52^{\mathrm{a}}$ & $8.00^{\mathrm{a}}$ & $7.34^{\mathrm{bc}}$ & $8.62^{\mathrm{a}}$ & $8.00^{\mathrm{ab}}$ \\
$(2)$ & $7.34^{\mathrm{bc}}$ & $7.40^{\mathrm{bc}}$ & $7.38^{\mathrm{bc}}$ & $8.00^{\mathrm{ab}}$ & $7.82^{\mathrm{b}}$ \\
$(3)$ & $7.68^{\mathrm{b}}$ & $6.75^{\mathrm{cd}}$ & $7.32^{\mathrm{bc}}$ & $8.23^{\mathrm{ab}}$ & $7.35^{\mathrm{b}}$ \\
$(4)$ & $8.30^{\mathrm{ab}}$ & $7.79^{\mathrm{b}}$ & $8.25^{\mathrm{a}}$ & $8.77^{\mathrm{a}}$ & $8.20^{\mathrm{ab}}$ \\
$(5)$ & $8.40^{\mathrm{a}}$ & $8.00^{\mathrm{a}}$ & $8.12^{\mathrm{ab}}$ & $8.22^{\mathrm{ab}}$ & $8.32^{\mathrm{a}}$ \\
\hline
\end{tabular}

( 1 ) Leaves juice ( $100 \%$ Moringa leaves ).

( 2 ) Leaves juice + pineapple juice $(1: 1, \mathrm{~V} / \mathrm{V})$.

( 3 ) Cooked seeds ( such as cooked peas).

( 4 ) Moringa tea $+25 \%$ dried cloves ( W/W).

( 5 ) Moringa tea $+25 \%$ dried peppermint (W/W).

Finally, through all data concerning different compounds existing in Moringa oleifera, it could be clearly concluded that Moringa is very rich in many important nutrients to human health such as energy releasing nutrients such as lipids and proteins including essential or non - essential amino acids, significant minerals which means that this crop worth to be studied or investigated.

Through the same study, it has been proved that it could be practically to utilize moringa different parts in producing very important and palatable economic products such as moringa tea, moringa juice and cooked seeds. It is also recommended to expand the area cultivated with moringa in future.

\section{REFERENCES}

1. AOAC. 1990. Official Methods of Analysis. Association of Official Analytical Chemists $15^{\text {th }}$ Ed., Arlington Virginia, U.S.A.

2. AOAC. 2000. Official Methods of Analysis. Association of Official Analytical Chemists, Washington, DC, USA.

3. Atawodi , S.E. , J.C. Atawodi, G.A. Idakwo, B. Pfundstein, R. Haubner, H. Bartsch, and R.W. Owen. 2010. Evaluation of the polyphenol content and antioxidant properties of methanol extracts of the leaves, stem, and root barks of Moringa oleifera Lam. J. Med. Food, 13, $710-716$.

4. Bassller, N.R. and H. Buchholz, 1993. Amino acid analysis. In : Methodenbuch Volume. 111, die chemische Untersuchung von Futtermitteln VDLUFA.Verlag, Darmstadt, Germany , Austria , $1-5$.

5. Bukar, A., A. Uba and T.I. Oyeyi. 2010. Antimicrobial profile of Moringa oleifera 
Lam. extract against some food - borne microorganisms. Bayero Journal of Pure and Applied Science, 3 ( 1 ) $43-48$.

6. Busani, M., J.M. Patrick, H. Arnold and M. Voster. 2011. Nutritional characterization of Moringa ( Moringa oleifera Lam. ) leaves. African Journal of Biotechnology, 10 ( 60 ) : 12925 - 12933.

7. Charles, W.Y,. and D.B. Marcel, S. Aly, A.N. Phillippe, A.T. Sabadenedyo. 2011. Determination of chemical composition and nutritional values of Moringa oleifera leaves. Pakistan Journal of Nutrition , 10(3) :264 - 268.

8. Compaore, W.R., P.A. Nikiema, H.I.N. Bassole, A. Savadego, J. Mouecoucou, D.J. Hounhouigan and S.A. Traore. 2011. Chemical composition and antioxidative properties of seeds of Moringa oleifera and pulps of Parkia biglobosa and Adansonia digitata commonly used in food fortification in Burkina Faso. Current Research Journal of Biological Science. 3 ( 1 ) : 64 - 72.

9. Cruess, W.V. 2000. Commercial fruit and vegetable products. New York, Toronto, London.

10. Foidl, N., H.P.S. Makkar and K. Becker. 2001. The potential of Moringa oleifera for agricultural and industrial uses. What development potential for Moringa products? October $20^{\text {th }}-$ November $2^{\text {nd }}$ 2001. Dar El - Salaam.

11. Goupy, P., M. Hugues, P. Boivin and M.J. Amoit. 1999. Antioxidant composition and activity of barley ( Hordeum vulgare ) and malt extracts and of isolated phenolic compounds. J. Sci. Food Agric., 79 : 1625 - 1634.

12. Hamed, H.S. 1980. Chemical and technological studies upon preservation of some fruits and vegetables. M.Sc. Thesis, Faculty of Agric. Menofiya University.

13. Jed, W.F. 2005. Moringa oleifera :A review of the medical evidence for its nutritional , therapeutic and prophylactic properties. Trees for Life Journal , 1:5.

14. Nzikou, I.M., L. Matos, J.E. Moussounga, C.B. Ndangu and A. Kimbonguila. 2009. Characterization of Moringa oleifera seed oil variety Congo Brazzaville. J. Food Technol., 7 ( 3 ) : $59-65$.

15. Rebecca, H.S.U., M. Sharon, A. Arbaunsyah and D. Lucienne. 2006. Moringa oleifera : medicinal and socio - economic uses : International Course on Economic Botany. National Herbarium Leiden, Netherlands S. PP. 2 -6.

16. Zhuang, X.P., Y.Y. Lu and G.S. Yang. 1992. Extraction and determination of flavonoid in ginko. Chinese Herbal Medicine, $23: 122-124$.

17. Zhang, D. and Y. Hamauzu. 2004. Phenolics, ascorbic acid, carotenoids and antioxidant activity of broccoli and their changes during conventional and microwave cooking. Food Chemistry, $88: 503-509$. 
نبــات المورينجا "القيمة الغذائيــة والاستفادة منه فحى التصنيـــع الغذائــي"

فاطمة حسن محمد المصري ، محمد الأمين محمد موسي ، سعد ميخائيل يوسف

قسم بحوث تصنيع الحاصلات البنتانية - معرة بحوث تكنولوجيا الأغنية - مركز الجوث الزراعية - الجيزة.

تم دراسة بعض الخصائص الطبيعية والتزكيب الكيماوي لأجز اء نبات المورينجا متل (القرون

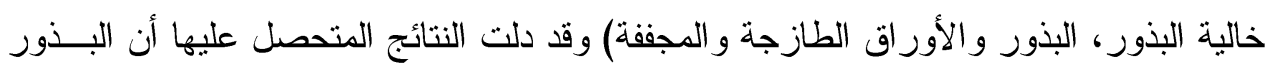

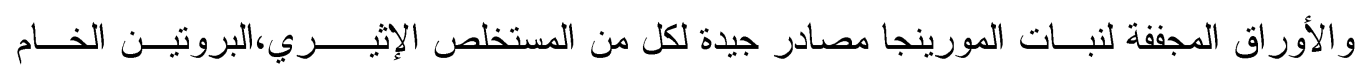

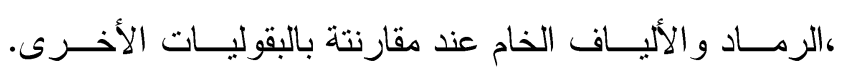

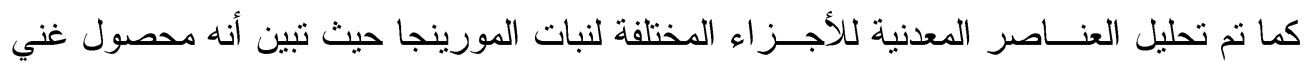

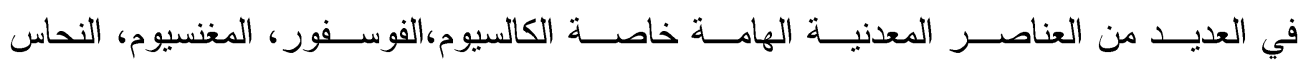

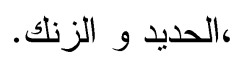

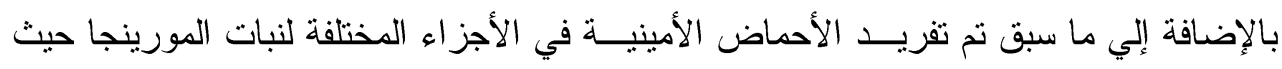

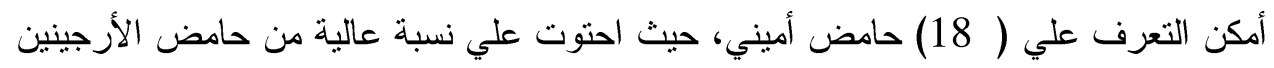

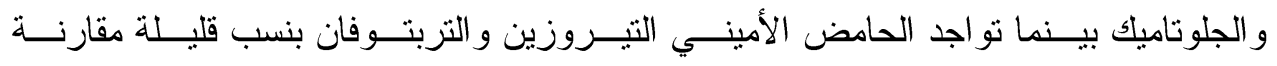
ببـاقي الأحماض الأمينيــة.

كذلك دلت النتائج المتحصل عليها أن الأجزاء المختلفة لنبات المورينجا من الصصادر الغنية

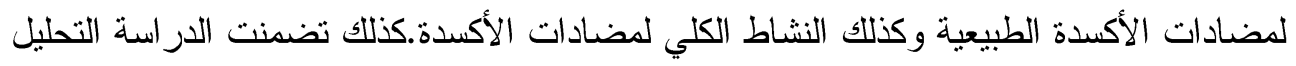

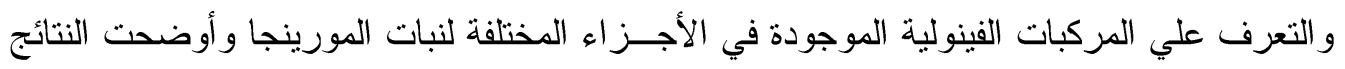

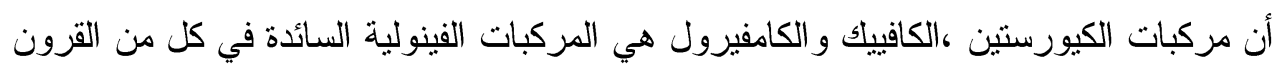

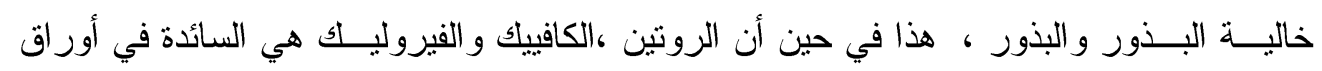
نبــات المورينــا الطازجــــة والمجفقة.

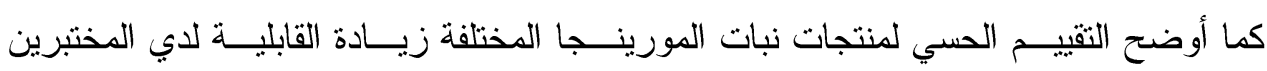

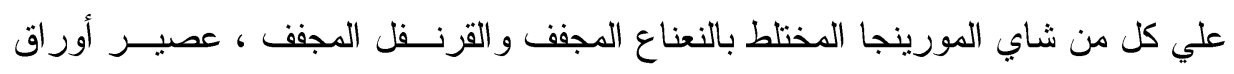

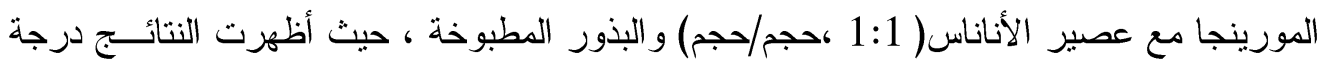

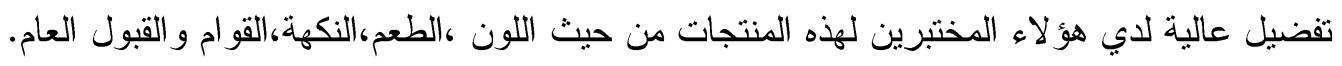

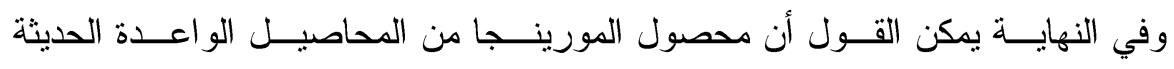

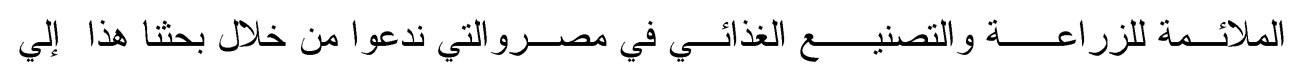

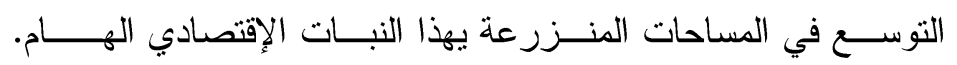

